\title{
MARTIN M.G. FASE RETIRES FROM THE BOARD OF THE EDITORS
}

\author{
BY
}

\author{
FRANZ C. PALM*
}

After 20 years Martin Fase has decided to retire from the editorial board of De Economist, one of the oldest professional journals in economics. In 1998, Martin became the managing editor of De Economist. During the last 5 years, he combined the chair of the board of editors and the managing editorship.

In the board, Martin will be remembered for his clear views on the policy of the journal and the exemplary service which he rendered to realize the policy goals. By continually emphasizing the importance of maintaining the scholarly standards of the journal and insisting on substance, relevance and quality rather than topicality of the contributions he helped shaping the editorial policy and the status of De Economist.

As chairman of the board, he provided leadership by initiating special issues on important problems, suggesting topics and areas in which papers could be solicited with the objective to continue to make the journal attractive and interesting for its readership.

As managing editor as well, Martin has been effective and efficient. He took pride in making sure that the review process was fast but did not compromise on quality. In his view, a prompt, high quality review process should be a distinctive and attractive feature of the journal. Indeed, as a managing editor and a board member, he contributed far more than his fair share to making De Economist renowned for this.

Martin Fase will also be remembered for his fine publications in the journal. Much of his work consists of careful empirical analysis, always theory-based and policy-relevant. It is first rate in terms of quality and meets the highest professional standards. His contributions over the years to the analysis of money demand in The Netherlands, Europe and the G7 have been path-breaking. Illustrative for the breadth of his work are his recent contributions on 'On Economics and Religion' and on still not well understood illusions in economics under the heading 'Four Examples of a Trompe-l'Oeil in Economics' which have appeared as Communications in De Economist. With his numerous book reviews he has provided useful, professionally often unrewarded service to the economics profession.

* Universiteit Maastricht/Vakgroep Kwantitatieve Economie, P.O. Box 616, 6200 MD, Maastricht, The Netherlands, e-mail: f.palm@ke.unimaas.nl 
It is with esteem and affection that the members of the editorial board join me in this token of appreciation and gratefulness to Martin for his numerous contributions in various roles and functions for the benefit of De Economist and its readership and for shared friendship.

Open Access This article is distributed under the terms of the Creative Commons Attribution Noncommercial License which permits any noncommercial use, distribution, and reproduction in any medium, provided the original author(s) and source are credited. 